\title{
Foreword: Investigating a Found Typescript
}

\author{
Elara Bertho
}

My investigation actually began quite by chance. While looking for the African sources of the historian Yves Person, I came across not only the notebooks containing the "oral sources" with which Person made his name, but a number of sources written by Africans. Oddly, I made my discovery in the archives of the African Studies Library at Person's former university in the rue Malher in Paris and it came as a surprise for more than one reason. ${ }^{1}$ First, it appeared that in the 1950s there were numerous African-written accounts of the history of Samori Touré, yet nowhere did Yves Person highlight the importance of that indigenous literature written by "local people of letters." ${ }^{2}$ Moreover, one of the accounts stands out: a 110-page text by one Djiguiba Camara, entitled "Essai d'Histoire Locale," and that is the text published here. As its title suggests, Camara's text recounts the history of Camara's own region, around a small village in the foothills of the Simandougou mountains in Upper Guinée. The village is called Damaro and the text recounts the story of the mythical migrations of the Camara, the wars of Samori Touré, the colonial conquests, and finally the period up to 1955 , when the document was written. I was convinced the source was of interest, but I was struggling to piece together the circumstances in which such a text might have been produced. At first, the author's family name - an extremely common one in Guinée - made it difficult to identify his descendants and an enquiry at the archives in Aix-en-Provence revealed nothing very conclusive about him.

The text's reasoning is sometimes obscure and requires explanation. So, working with Marie Rodet, I began to edit it with a view to publishing it. I began by systematically reviewing Yves Person's Samori Touré: Une Révolution Dyula to find and highlight the passages of the typescript which the French historian had made use of. It was then that I realised that Djiguiba Camara

1 Yves Person's reference work, which took him a lifetime to produce, is Samori, une révolution dyula (Paris: IFAN/ Centre de recherches africaines, 1968-1975). Yves Person's personal archives can be found in the Bibliothèque de Recherches Africaines, Paris 1. I assisted Michèle Raffutin, the library's director and archivist, in the first project to catalogue this collection, and helped to classify and reference it on the website "Calames." At that time, Yves Person's archives were on open shelves, and available to anyone. Now, they may be consulted only on request but are fully referenced. The catalogue is online at: http://www.calames.abes.fr/pub/ \#details?id=FileId-1255 [consulted 24 May 2018].

2 Two African written sources have been transcribed as appendices to my thesis: Bertho 2016 II, 6o9-635 ("Entretiens" by Babou Kondé and “Notes historiques" by Tidiane Dem).

(C) ELARA BERTHO, 2020 | DOI:10.1163/9789004424876_007

This is an open access chapter distributed under the terms of the CC BY-NC 4.o license 
was certainly one of the most frequently quoted African sources for strategic periods of the colonial conquest. He also offers precious information on the precolonial period, particularly for the early years of Samori Touré's reign, when Touré was expanding in Upper Guinée. It was time-consuming philological work requiring enormous patience; sometimes it was even a little tedious, but it allowed us to prove that in a number of instances our intuitions had been correct about how Europeans had made use of African sources. But the work came to an abrupt halt when we received an email ...

On 30 June 2015 El Hadj Daouda Damaro Camara and Commandant N'Faly Camara had both signed a letter, instructing us to cease all plans to publish our work. Indeed, they threatened to sue us if we "misappropriated even one line of this manuscript," reminding us that "Guinean and French laws protect literary works and their authors." The letter's hostile tone left both Marie and me speechless for a moment. We eventually responded apologetically, for we had come to realise that we had touched on sensitivities of which we had previously been unaware.

It seemed that the document had embarked on a life of its own after its use by Yves Person, because El Hadj Daouda Damaro Camara, son of Djiguiba, maintained that he had significantly enhanced ("enrichi") his father's text. We had not known that; indeed, it was the first time we had heard of what had become of this wonderful manuscript, "Essai d'histoire locale." The abrupt responses from Djiguiba Camara's descendants following the unexpected email dissuaded Marie and me from going on with our work of editing and annotation. I for my part continued my thesis on Samori Touré, and the months went by... We became used to the idea that our publication was not to be".

In December 2015 another stroke of fate brought together Marie Rodet and the Assembly Member Mohamed Touré. Mohamed Touré is the son of Sékou Touré, the former President of Guinée, and on meeting Marie he promised her that he would act as intermediary between us and the Camara family. A remarkable offer, since within Guinée's contemporary politics, Mohamed Touré stands at the opposite end of the political spectrum from the Camara family. One member of the Camara family is the eminent Ahmadou Damaro Camara, properly known as "the Honourable Camara" in Guinée. He is the Leader of the Presidential Majority in the National Assembly, no less, and special advisor to President Alpha Condé. However, despite the differences in his political views, Mohamed Touré interceded for us and the Honourable One proved particularly amenable to such an unorthodox approach. We were officially invited to meet the Camara family in Conakry.

Thanks to funding from the British Academy, we arrived in Conakry in December 2016, although without any real idea of what to expect. We were 
greeted with curiosity by the representatives of the Camara family. Those of them who were from the actual village of Damaro added its name to their own family names, just like the Damaro who appear in "Essai d'Histoire Locale." During a courtesy visit to the Honourable One we learned that we were expected in the village, 800 kilometres away. Vehicles needed for our journey had been reserved, and El Hadj Daouda Damaro Camara would come with us, as would various other members of the family who wanted to join the team. Since everything seemed to have been decided, we felt we had no choice but to go along with the schedule prepared for us and, after two full days of travelling we finally arrived in the village. We were surprised to see that Djiguiba Camara's concession had been repainted for the occasion. His name jumped out at us in brilliant blue and red letters, along with the dates of his term as chief of the canton. We had come with a camera to record interviews; it now also served to film the receptions organised to celebrate our arrival, as well as the moving testimonies of those who had known Djiguiba Camara. Mawa Koné, one of his wives, wept with joy at our arrival. The villagers seemed to take the camera as a sign of our valuing of the village's cultural heritage. Against my expectations, it helped to loosen tongues and release memories. Our hosts found us a pair of antiquated typewriters which they fished up from inside two large iron trunks. The concession's shelving units held a mixture of yellowing papers from the time of the French administration, old hurricane lamps, and posters from past elections. Genealogies, lists of the inhabitants of surrounding villages, and collections of the Bulletin de l'Afrique française were piled up haphazardly. El Hadj Daouda Damaro Camara had shared our car throughout the journey and gradually, the more he came to trust us, he began to tell us his father's story.

Djiguiba Camara had written "Essai d'Histoire Locale" with the ambition of having it published. El Hadj Daouda Damaro Camara then accused Yves Person of extracting the work from him in exchange for what turned out to be a false promise that it would be published in France. The French historian was a plagiarist, said the younger Camara; ${ }^{3}$ El Hadj Daouda Damaro Camara said that, all his life, he had had his heart set on enhancing ("enrichir") his father's document. Many times he applied the metaphor of building to explain the

3 This publication is not concerned with bringing accusations against any party: by presenting the undercurrents of Africanist research, we will endeavour to shed light on the status of a little-known scholar from Guinée and analyse his relationship with the French administrator and historian Yves Person, while describing the painful memory which this intellectual "exchange" represents for the Camara family. Here, we shall consider both ways in which this history is remembered and recorded. 
encyclopaedic undertaking. ${ }^{4}$ His father had laid the foundations of a house, and he had taken up the responsibility for the rest of the construction. It was he who would decorate the walls, put glass in the windows, and make the roof weather-proof. Today, the text is over two thousand pages long, a vast work that is both composite and fascinating. The text now encompasses the history of the transatlantic slave trade, of the founding myths of the surrounding towns and of colonisation. It integrates lists of Malinké family names, proverbs, and much more. This was the first time he had brought it to the village, and the two elegantly bound volumes stood in pride of place in the concession throughout our stay in Damaro. Young and old alike adopted the text. They would read a few lines, casting their eyes over the numerous illustrations, and they eagerly discussed certain passages.

When we returned to Conakry, the family held a meeting while we recovered from the tiring journey. On leaving the meeting - which could be described, diplomatically, as "a bit long" - El Hadj Daouda Damaro Camara and Mamadi Camara came to find us. The family had made the formal decision to give us the right to publish their ancestor's manuscript in Europe, and they asked us to do all we could to promote his work..$^{5}$ On behalf of the extended family El Hadj Daouda and Mamadi Damaro Camara would take it upon themselves to follow our progress with the project. It is important to mention here that Djiguiba Camara had sixteen wives: Daouda is responsible for his father's spiritual legacy. El Hadj Daouda Damaro Camara is undertaking the task because he knows the texts best and because of his work collecting the stories of the region. Meanwhile, Mamadi Damaro Camara is the eldest of the grandchildren, so that between them the two represent the interests of the whole Damaro Camara family. Their agreement therefore allowed us to think about resuming our work for publication of the text while also suggesting multiple lines of inquiry we could never have imagined before this strange fieldwork trip.

Not only had he met Yves Person and become one of his best African sources, but Djiguiba Camara saw himself as a historian in his own right and had wanted his work to be published to affirm his status as a "man of letters." He had done everything in his power to obtain that symbolic legitimacy, but it was denied

4 On the idea of an "encyclopaedic undertaking," see the thesis, Ninon Chavoz, La Tentation encyclopédique dans les littératures francophones africaines: des documentations coloniales au glossaire contemporain, Forthcoming doctoral thesis, supervised by Xavier Garnier, Sorbonne Nouvelle Paris 3, 2018.

5 As part of the agreement Jan Jansen will support the Camara family to publish the voluminous enhanced version in collaboration with the African Studies Center Leiden, The Netherlands. 


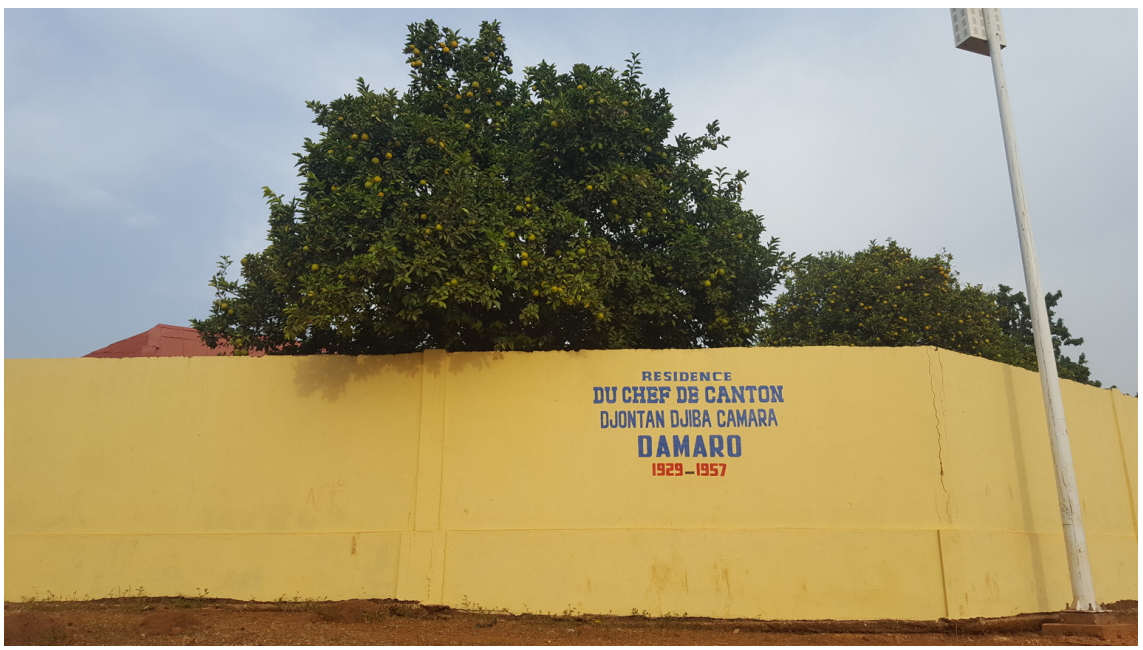

ILL. 6

Le mur de la concession de Djiguiba Camara à Damaro, photographie de 2016 d'Elara Bertho et Marie Rodet / Wall of Djiguiba Camara's compound in Damaro, photograph by Elara Bertho and Marie Rodet, 2016

him during his lifetime, leaving his family with bitter memories. Our own plans to publish the text therefore, which we of course thought of as a means of recognising the value of colonial intermediaries, had in fact only managed to rekindle postcolonial fears. Here we were, seventy years after Yves Person, reappearing as an unwelcome reminder of a painful encounter which the Camara had experienced as a pillaging of their culture. Indeed, as white female scholars, one can never research Africa in a neutral way.

What may be seen as more astonishing still is what happened to Djiguiba Camara's text after his encounter with Yves Person, which itself is like something from a novel. The text was taken into custody by El Hadj Daouda Damaro Camara who took it with him to Côte d'Ivoire when he decided to flee Sékou Touré's regime in 1972. Since then it grew steadily, until it came back to Guinée with El Hadj Daouda Damaro Camara. From the late 196os, El Hadj Daouda Damaro Camara even re-established contact with Yves Person in an attempt to recover his father's photographs, and once again to seek support for publication of the text. ${ }^{6}$ El Hadj Daouda Damaro Camara also corresponded with Denise

6 Letter from Yves Person to Daouda Camara, dated March 1968, Université de Dakar, Humanities and Social Sciences Faculty, History Department. Letter from Yves Person to Daouda Camara, dated 14 April 1972, Université de Paris, Humanities and Social Sciences Faculty, African Studies Centre. El Hadj Daouda Damaro Camara's personal archives, Conakry. 
Bouche, Ibrahima Baba Kaké and Ahmadou Hampaté Bâ. ${ }^{7}$ Quite simply, this text is his life's work.

Since our visit to the village the dialogue, which truly began then, has been unceasing. We communicate regularly via email and telephone and thanks to a British research grant I was able to go back with Jan Jansen to Conakry, and then to Damaro, in January and February of 2018. ${ }^{8}$ I returned again briefly in April 2018. Each time El Hadj Daouda Damaro Camara accompanied us and, with the same unwavering enthusiasm, recounted his father's story, along with anecdotes from the colonial period and the memory of his achievements in the region.

7 Interview with El Hadj Daouda Damaro Camara, Conakry, 23 December 2016.

8 ESRC "Resilience in West African Frontier Communities" (Es/ROo280o/1) led by Marie Rodet in collaboration with Friederike Lüpke, Bakary Camara and Elara Bertho, and the Malian NGO Donkosira. 